\title{
FAKTOR-FAKTOR YANG MEMPENGARUHI PRICE EARNING RATIO SAHAM LQ45 DI INDONESIA
}

\author{
Taruna \\ Program Studi Magister Manajemen Universitas Tarumanagara \\ taruna2793@gmail.com \\ Carunia Mulya Firdausy \\ Program Studi Magister Manajemen Universitas Tarumanagara
}

\begin{abstract}
Abstratct : The purpose of this research is to analyze factors that influence price earning ratio of LQ45 index in Indonesia for the year 2013-2016. Sample was collected by using purposive sampling method. Based on the type of data and analysis, this research is called quantitative research and data used is secondary data. The results of this study indicate that dividend payout ratio and price book value affected the price earning ratio of LQ45, while return on equity, earnings per share growth and financial leverage have no effect on PER of LQ45 stock. Simultaneously, all the independent variables significantly influence the PER stock of LQ45. Based on the coefficient of determination can be concluded that all the independent variables affect the price earning ratio of LQ45 stock by $25.46 \%$.
\end{abstract}

Keywords : Dividend Payout Ratio, Earning Per Share Growth, Return On Equity, Price Book Value, Financial Leverage, Price Earning Ratio.

\section{PENDAHULUAN}

Pada awal tahun 2016, harga saham banyak mengalami pembetulan. Hal ini dikarenakan kondisi ekonomi yang melemah pada tahun sebelumnya. Pada tahun 2015, banyak investor menginvestasikan dana pada perusahaan yang mangalami penurunan harga saham. Salah satu perusahaan yang diminati pada saat itu adalah Surya Semesta Internusa Tbk (SSIA). Surya Semesta Internusa Tbk (SSIA) memiliki PER yang cukup rendah tetapi harga saham Surya Semesta Internusa Tbk (SSIA) tidak mengalami kenaikan selama enam bulan. Terdapat beberapa faktor yang dapat mengindikasikan mengapa harga saham Surya Semesta Internusa Tbk (SSIA) tidak mengalami kenaikan, yaitu seperti kondisi perusahaan yang kurang likuid. Di sisi lain, perusahaan lain seperti Pakuwon Jati Tbk (PWON) memiliki PER yang tidak beda jauh dengan Surya Semesta Internusa Tbk (SSIA) tetapi harga saham Pakuwon Jati Tbk (PWON) melambung tinggi dalam waktu delapan bulan.

Ada beberapa faktor yang harus diperhatikan dalam menganalisis PER. Faktor yang harus diperhatikan adalah pembagian deviden perusahaan, likuiditas, solvabilitas dan juga pertumbuhan EPS. Pemegang saham (investor) dalam melakukan investasi memerlukan beberapa informasi penting tentang perusahaan. Hal ini digunakan pemegang saham (investor) untuk memprediksi sejauh mana prestasi perusahaan dari saham yang akan dipilih serta keuntungan optimal yang akan diperoleh. Informasi tersebut dapat membantu investor untuk meminimalisir resiko dalam pengambilan keputusan. Oleh karena itu, penelitian ini bertujuan untuk mengetahui dan menganalisis faktor-faktor yang dapat mempengaruhi price earning ratio saham LQ45 di Indonesia.

\section{LANDASAN TEORI}

Menurut Murhadi (2013), dividend payout ratio merupakan rasio yang menggambarkan besarnya proporsi dividen yang dibagikan terhadap pendapatan bersih perusahaan. Sedangkan menurut Hanafi dan Halim (2009) mengemukakan bahwa dividend 
payout ratio merupakan rasio pembayaran dividen yang melihat bagian earnngs (pendapatan) yang dibayarkan sebagai dividen kepada investor. Perusahaan hanya bisa membagikan dividend besar jika perusahaan mampu menghasilkan laba yang semakin besar.

Return On Equity (ROE) adalah kemampuan perusahaan dalam menghasilkan keuntungan modal sendiri yang dimiliki. Menurut Sawir (2005:20) menyatakan bahwa ROE merupakan sebuah rasio yang sering dipergunakan oleh pemegang saham untuk menilai kinerja perusahaan yang bersangkutan. ROE mengukur besarnya tingkat pengembalian modal dari perusahaan. Semakin tinggi ROE, maka semakin tinggi permintaan investor untuk membeli saham.

Price to Book Value (PBV) menurut Husnan. S dan Pudjiastuti (2006), merupakan perbandingan antara harga pasar dan nilai buku saham. Untuk perusahaan-perusahaan yang berjalan dengan baik, umumnya rasio ini mencapai diatas satu, yang menunjukkan bahwa nilai pasar saham lebih besar dari nilai bukunya. Semakin besar rasio PBV semakin tinggi perusahaan dinilai oleh para pemodal relatif dibandingkan dengan dana yang telah ditanamkan di perusahaan.

Earning Per Share merupakan ukuran kemampuan perusahaan untuk menghasilkan keuntungan perlembar saham pemilik. Menurut Fahmi (2012:138), Earning Per Share (EPS) atau pendapatan saham perlembar adalah bentuk pemberian keuntungan yang diberikan kepada para pemegang saham dari setiap lembar saham dimiliki.

Menurut Martono dan Harjito (2008:301), mengemukakan bahwa Financial Leverage merupakan penggunaan dana dengan beban tetap dengan harapan atas penggunaan dana tersebut akan memperbesar pendapatan per lembar saham (earning per share, EPS).

Sudana (2011), mengemukakan bahwa Price Earning Ratio adalah rasio yang mengukur tentang bagaimana investor menilai prospek pertumbuhan perusahaan di masa yang akan datang, dan tercermin pada harga saham yang bersedia dibayar oleh investor untuk setiap rupiah laba yang diperoleh perusahaan.

\section{Hipotesis Penelitian}

$\mathrm{Ha}_{1}$ : Terdapat pengaruh Deviden payout ratio (DPR) terhadap price earning ratio (PER) saham LQ45 di Indonesia.

$\mathrm{Ha}_{2}$ : Terdapat pengaruh Return on equity (ROE) terhadap price earning ratio (PER) saham LQ45 di Indonesia.

$\mathrm{Ha}_{3}$ : Terdapat pengaruh Price Book Value (PBV) terhadap price earning ratio (PER) saham LQ45 di Indonesia.

Ha4: Terdapat pengaruh Earning Per share growth (EPSG) terhadap price earning ratio (PER) saham LQ45 di Indonesia.

Ha5: Terdapat pengaruh Financial Leverage (FLEV) terhadap price earning ratio (PER) saham LQ45 di Indonesia.

Ha6: Terdapat pengaruh Dividend payout ratio, Return on equity, Price Book Value, earning growth dan Financial Leverage secara bersama-sama terhadap price earning ratio (PER) saham LQ45 di Indonesia.

\section{METODE PENELITIAN}

Penelitian ini termasuk dalam penelitian kuantitatif karena menggunakan data dalam bentuk angka. Periode penelitian yaitu tahun 2013-2016.

Populasi dari penelitiaan ini adalah perusahaan yang masuk dalam perhitungan indeks LQ 45 periode tahun 2013 sampai dengan tahun 2016, yaitu sebesar 45 perusahaan. Sampel ditentukan menggunakan metode purposive sampling. Kriteria dalam penelitian ini adalah(a) Perusahaan yang memiliki laba positive selama periode pengamatan yaitu periode 2013-2016, (b) Perusahaan tersebut tidak mengalami delisting dari perhitungan saham LQ45 selama periode penelitian, (c) Perusahaan tersebut membagikan deviden pada periode pengamatan, 
(d) Memiliki data keuangan yang lengkap. Objek yang akan diteliti adalah perusahaan yang masuk dalam perhitungan indeks LQ 45.

Jenis data sekunder yang digunakan adalah data eksternal berupa laporan keuangan perusahaan LQ45 yang diperoleh dari Laporan Keuangan yang dipublikasikan di Bursa Efek Indonesia tahun 2013-2016.

\section{Operasionalisasi Variabel.}

Penelitian ini menggunakan dua jenis variabel, yaitu variabel independen dan variabel dependen.

\section{Tabel I}

\begin{tabular}{|c|c|c|}
\hline Variabel & Definisi Variabel & Pengukuran \\
\hline $\begin{array}{l}\text { Dividend } \\
\text { Payout } \\
\text { Ratio }\left(\mathrm{X}_{1}\right)\end{array}$ & $\begin{array}{l}\text { Dividend payout ratiomenunjukkan } \\
\text { persentase laba perusahaan yang } \\
\text { dibayarkan kepada pemegang saham secara } \\
\text { tunai. Pembagian dividend yang besar } \\
\text { sangat diingkan oleh investor namun bila } \\
\text { dividen payout ratio nya lebih besar dari } \\
25 \% \text { maka akan terjadi kesulitan likuiditas } \\
\text { perusahaan dimasa yang akan datang. }\end{array}$ & $\frac{\text { Dividend per share }}{\text { Earning per share }} \times 100 \%$ \\
\hline $\begin{array}{l}\text { Return On } \\
\text { Equity }\left(\mathrm{X}_{2}\right)\end{array}$ & $\begin{array}{l}\text { Retuen on equity menunjukkan daya untuk } \\
\text { menghasilkan laba atas investasi } \\
\text { berdasarkan nilai buku para pemegang } \\
\text { saham, dan sering kali digunakan dalam } \\
\text { membandingkan dua atau lebih perusahaan } \\
\text { atas peluang investasi yang baik dan } \\
\text { manajemen biaya yang efektif. }\end{array}$ & $\frac{\text { Net income }}{\text { Total Equity }}$ x $100 \%$ \\
\hline $\begin{array}{c}\text { Price book } \\
\text { value }\left(\mathrm{X}_{3}\right)\end{array}$ & $\begin{array}{l}\text { Price to Book Value ini menunjukan } \\
\text { seberapa jauh sebuah perusahaan mampu } \\
\text { menciptakan nilai perusahaan relatif } \\
\text { terhadap jumlah modal diinvestasikan. }\end{array}$ & $\frac{\text { Harga saham }}{\text { Nilai buku per saham }}$ \\
\hline $\begin{array}{c}\text { EPS } \\
\text { Growth }\left(\mathrm{X}_{4}\right)\end{array}$ & $\begin{array}{l}\text { Pertumbuhan EPS mencerminkan tingkat } \\
\text { pertumbuhan laba per saham setiap } \\
\text { periode. }\end{array}$ & $\frac{E P S_{t-} E P S_{t-1}}{E P S_{t-1}}$ \\
\hline $\begin{array}{c}\text { Financial } \\
\text { leverage }\left(\mathrm{X}_{5}\right)\end{array}$ & $\begin{array}{l}\text { Financial Leverage (X5) adalah } \\
\text { perbandingan antara jumlah utang dengan } \\
\text { jumlah aktiva yang menggambarkan } \\
\text { sampai seberapa besar perusahaan } \\
\text { menggunakan hutang dalam struktur } \\
\text { modal. }\end{array}$ & $\frac{\text { Total Aktiva }}{\text { Total Hutang }}$ x $100 \%$ \\
\hline $\begin{array}{l}\text { Price earning } \\
\quad \text { Ratio }(\mathrm{Y})\end{array}$ & $\begin{array}{l}\text { Price Earning Ratio (PER) digunakan oleh } \\
\text { para investor untuk memprediksi } \\
\text { kemampuan perusahaan dalam } \\
\text { menghasilkan laba dimasa yang akan } \\
\text { datang. }\end{array}$ & $\frac{\text { Price Stock }}{\text { Earning per share }} \times 100 \%$ \\
\hline
\end{tabular}


Metode analisis data yang digunakan adalah metode analisis statistik dengan persamaan regresi berganda dengan bantuan program pengolahan software Eviews 9 . Sebelum melakukan pengujian hipotesis dengan metode analisis regresi berganda terlebih dahulu dilakukan analisis statistik deskriptif dan uji asumsi klasik. dimana:

$$
\mathrm{PER}=\mathrm{a}+\mathrm{b} 1 \mathrm{DPR}+\mathrm{b} 2 \mathrm{ROE}+\mathrm{b} 3 \mathrm{PBV}+\mathrm{b} 4 \mathrm{EPS} \text { growth + b5 FL + e }
$$

PER : : Price Earning Ratio dengan satuannya kali.

DPR : Dividend Payout Ratio dengan satuannya persentase.

ROE $\quad$ : Return on Equity dengan satuannya persentase.

PBV : Price Book Value dengan satuannya kali.

EPS Growth $\quad$ : Pertumbuhan Laba dengan satuannya kali

FL : Financial Leverage dengan satuannya persentase

a : Konstanta, b : Koefisien Regresi, e : Variabel residual

\section{HASIL DAN PEMBAHASAN \\ Stastik Deskriptif}

Tabel II menunjukkan statistic deskriptif dari variabel dependen (terikat) Price Earning Ratio (PER) dan lima variabel independen (bebas) yaitu Dividend Payout Ratio (DPR), Return on Equity (ROE), Price Book Value (PBV), Earning Growth (EPS_G) dan Financial Leverage (FLEV).

Tabel II

\begin{tabular}{lcccccc}
\hline & DPR & PBV & PER & ROE & EPS_G & FLEV \\
\hline Mean & 42.62676 & 5.465147 & 19.01294 & 22.45265 & 0.067523 & 0.512787 \\
Maximum & 99.93000 & 58.48000 & 48.24000 & 135.8500 & 1.138120 & 1.214858 \\
Minimum & 4.090000 & 0.360000 & 5.120000 & 4.500000 & -0.438376 & 0.133061 \\
Std. Dev. & 20.95293 & 11.20259 & 9.620633 & 26.85735 & 0.262229 & 0.249130 \\
\hline Observations & 68 & 68 & 68 & 68 & 68 & 68 \\
\hline
\end{tabular}

Dari output di atas diperoleh deskripsi data pada variabel penelitian sebagai berikut :

a. Dari 68 data DPR mempunyai nilai mean sebesar 42.62676 dengan nilai maksimum sebesar 99.93000 dan nilai minimum sebesar 4.090000 serta nilai standard deviasi sebesar 20.95293.

b. Dari 68 data PBV mempunyai nilai mean sebesar 5.465147 dengan nilai maksimum sebesar 58.48000 dan nilai minimum sebesar 0.360000 serta nilai standard deviasi sebesar 11.20259.

c. Dari 68 data PER mempunyai nilai mean sebesar 19.01294 dengan nilai maksimum sebesar 48.24000 dan nilai minimum sebesar 5.120000 serta nilai standard deviasi sebesar 9.620633 .

d. Dari 68 data ROE mempunyai nilai mean sebesar 22.45265 dengan nilai maksimum sebesar 135.8500 dan nilai minimum sebesar 4.500000 serta nilai standard deviasi sebesar 26.85735.

e. Dari 68 data EPS_G mempunyai nilai mean sebesar 0.067523 dengan nilai maksimum sebesar 1.138120 dan nilai minimum sebesar-0.438376 serta nilai standard deviasi sebesar 0.262229 .

f. Dari 68 data FLEV mempunyai nilai mean sebesar 0.512787 dengan nilai maksimum sebesar 1.214858 dan nilai minimum sebesar 0.133061 serta nilai standard deviasi sebesar 0.249130 . 


\section{Uji Asumsi Klasik}

\section{1) Uji Multikolinearitas}

Regresi yang menggunakan lebih dari satu variabel independen harus tidak terjadi multikolinearitas (hubungan linear) diantara variabel-variabel independen.

Tabel III

\begin{tabular}{crrrrc}
\hline & \multicolumn{1}{c}{ DPR } & \multicolumn{1}{c}{ EPSG } & \multicolumn{1}{c}{ FLEV } & PBV & ROE \\
\hline DPR & 1.000000 & -0.175238 & -0.164103 & 0.388363 & 0.316790 \\
EPSG & -0.175238 & 1.000000 & 0.091784 & 0.020929 & 0.060857 \\
FLEV & -0.164103 & 0.091784 & 1.000000 & 0.273450 & 0.345155 \\
PBV & 0.388363 & 0.020929 & 0.273450 & 1.000000 & 0.974438 \\
ROE & 0.316790 & 0.060857 & 0.345155 & 0.974438 & 1.000000 \\
\hline
\end{tabular}

Tabel di atas menunjukkan bahwa koefisien korelasi antara variabel PBV dan ROE sebesar $0.974438>0.80$. Hal ini memberi arti bahwa asumsi tidak terjadi multikolinearitas tidak dapat dipenuhi. Untuk menghilangkan gejala Multikolinearitas dan Heteroskedastisitas dilakukan transformasi data dengan nilai first difference dengan rumus: $\mathrm{X}=\left(\mathrm{X}_{\mathrm{t}}-\mathrm{X}_{\mathrm{t}-1}\right)$ dan $\mathrm{Y}$ $=\left(\mathrm{Y}_{\mathrm{t}}-\mathrm{Y}_{\mathrm{t}-1}\right)$ Sehingga untuk setiap sampel yang awalnya terdapat empat data dari tahun 2013 sampai dengan tahun 2016 menjadi tiga data, yaitu tahun 2014 sampai dengan 2016. Dengan demikian data observasi menjadi 51 (periode $\mathrm{t}=3$ dan unit $\mathrm{n}=17$ ).

Tabel IV

\begin{tabular}{crrrrr}
\hline & \multicolumn{1}{c}{ DPR } & \multicolumn{1}{c}{ EPSG } & \multicolumn{1}{c}{ FLEV } & \multicolumn{1}{c}{ PBV } & \multicolumn{1}{c}{ ROE } \\
\hline DPR & 1.000000 & -0.133817 & 0.290255 & 0.439080 & -0.419819 \\
EPSG & -0.133817 & 1.000000 & -0.070515 & 0.050112 & 0.596411 \\
FLEV & 0.290255 & -0.070515 & 1.000000 & 0.045729 & -0.106085 \\
PBV & 0.439080 & 0.050112 & 0.045729 & 1.000000 & -0.351751 \\
ROE & -0.419819 & 0.596411 & -0.106085 & -0.351751 & 1.000000 \\
\hline
\end{tabular}

Setelah melakukan transformasi first difference, table IVmenunjukkan bahwa sudah tidak ada antar variabel independen yang koefisien korelasinya $>0.80$ dengan demikian asumsi tidak terjadi multikolinearitas dipenuhi.

\section{2) Uji Heteroskedastisitas}

Asumsi klasik dalam regresi data panel yang harus dipenuhi selain tidak terjadi multikolinearitas adalah tidak terjadi heteroskedastisitas (homoskedastisitas) artinya variabsi dari residual tetap (konstan).

\section{Tabel V}

Heteroskedasticity Test: White

\begin{tabular}{|c|c|c|c|}
\hline F-statistic & 0.366575 & $\begin{array}{l}\text { Prob. F(20,30) } \\
\text { Prob. Chi- }\end{array}$ & 0.9889 \\
\hline Obs*R-squared & 10.01585 & quare(20) & 0.9679 \\
\hline $\begin{array}{l}\text { Scaled explained } \\
\text { SS }\end{array}$ & 15.30241 & $\begin{array}{l}\text { Prob. Chi- } \\
\text { quare(20) }\end{array}$ & 0.758 \\
\hline
\end{tabular}

Pada tabel di atas, menunjukkan bahwa probabilitas signifikansi statistik $O b s^{*}$ Rsquared sebesar $0.9679>0.05$ dengan demikian asumsi tidak terjadi Heteroskedastisitas dipenuhi 


\section{Proses Pemilihan Model Penelitian}

\section{1) Uji Chow}

Dari tabel di bawah (table VI) dapat diketahui bahwa probabilitas signifikansi Crosssection $F$ sebesar $0.6681>0.05$. Sehingga Common Effect Model merupakan model yang lebih baik dari Fixed Effect Model.

\section{Tabel VI}

Redundant Fixed Effects Tests

Equation: CHOW

Test cross-section fixed effects

\begin{tabular}{llrc}
\hline \hline Effects Test & Statistic & d.f. & Prob. \\
\hline \hline Cross-section F & 0.806519 & $(16,29)$ & 0.6681 \\
\hline \hline
\end{tabular}

\section{2) Uji Haussman Test}

\section{Tabel VII}

Correlated Random Effects - Hausman Test

Equation: HAUSMAN

Test cross-section random effects

\begin{tabular}{lcrc}
\hline \hline Test Summary & $\begin{array}{r}\text { Chi-Sq. } \\
\text { Statistic }\end{array}$ & $\begin{array}{r}\text { Chi-Sq. } \\
\text { d.f. }\end{array}$ & Prob. \\
\hline \hline Cross-section random & 1.027914 & 5 & 0.9603 \\
\hline \hline ** WARNING: estimated cross-section random effects variance is \\
zero.
\end{tabular}

Dari tabel di atas dapat diketahui bahwa probabilitas chi-squaresebesar $0.9603>$ 0.05sehingga Random Effect Modelterpilih sebagai model terbaik yang akan digunakan dalam penelitian ini.

Uji Hipotesis. Setelah mendapat model terbaik dari dua pengujian yaitu uji chow dan uji hausman, dan kedua hasil uji tersebut menjawab bahwa data panel yang akan diolah menggunakan Common Effect Model. Berikut tabel hasil dengan menggunakan Common Effect Model. 


\section{Tabel VIII}

Dependent Variable: PER

Method: Panel EGLS (Cross-section random effects)

Date 04/20/18 Time: 16:40

Sample: 20142016

Periods included: 3

Cross-sections included: 17

Total panel (balanced) observations: 51

Swamy and Arora estimator of component variances

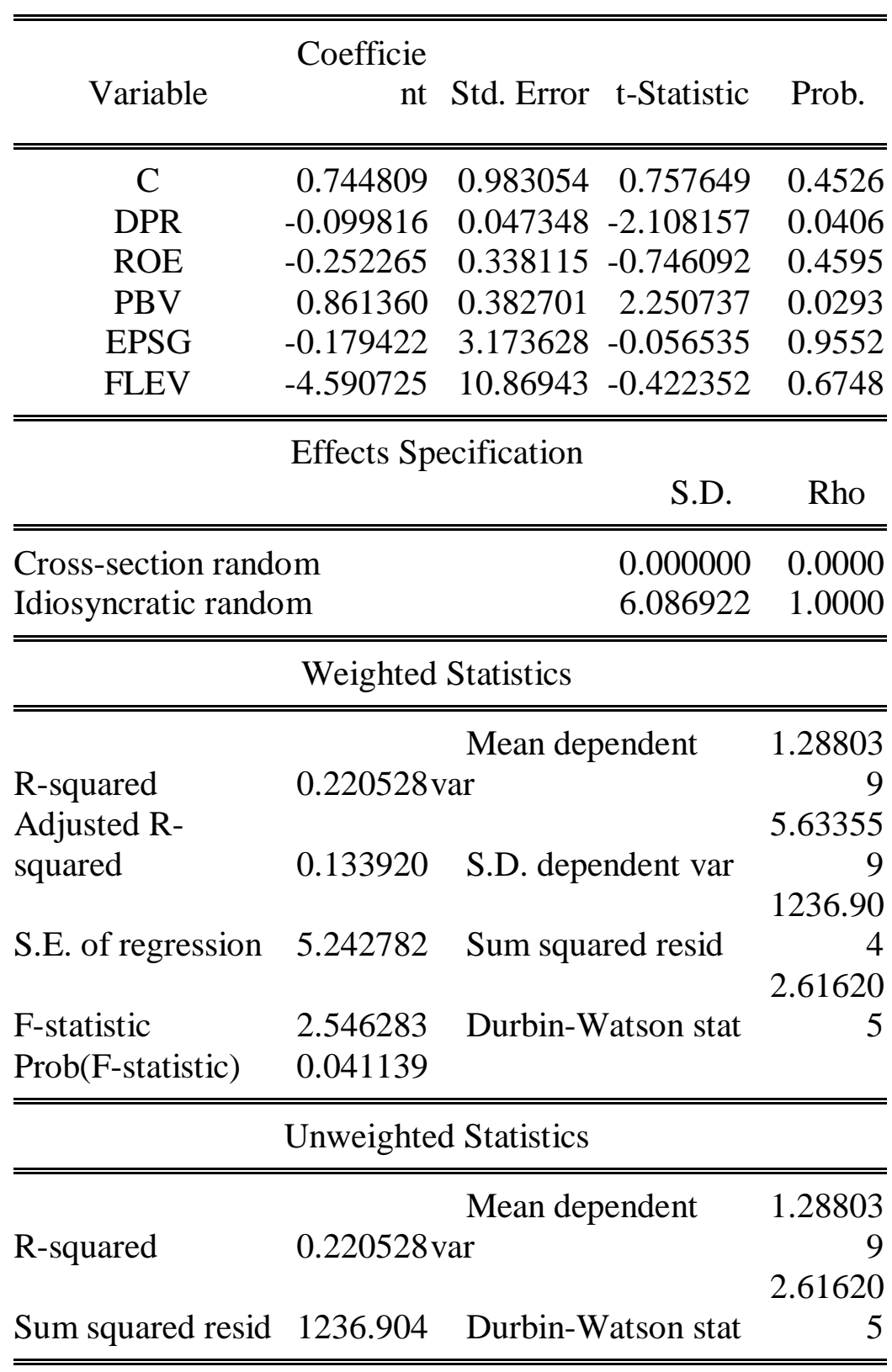

Hasil Uji Regresi Berganda. Dengan menggunakan bantuan eviews 9, hasil perhitungan koefisien regresi antara variable, diperoleh persamaan regresi sebagai berikut:

$$
\begin{gathered}
\mathrm{PER}=0.744809-0.099816^{*} \mathrm{DPR}-0.252265^{*} \mathrm{ROE}+0.861360 * \mathrm{PBV} \\
-0.179422^{*} \mathrm{EPSG}-4.590725^{*} \mathrm{FLEV}
\end{gathered}
$$

Interpretasi dari persamaan di atas adalah: 
a) Nilai konstanta sebesar 0.744809 menunjukkan besarnya nilai PER jika nilai variabel independen DPR, ROE, PBV, EPS_G dan FLEV konstan atau nol.

b) Koefisien regresi DPR sebesar -0.099816 menunjukkan besarnya pengaruh DPR terhadap PER negatif. Artinya, jika nilai DPR naik sebesar satu satuan, maka nilai PER akan turun sebesar 0.099816 satuan.

c) Koefisien regresi ROE sebesar -0.252265 menunjukkan besarnya pengaruh ROE terhadap PER negatif. Artinya, jika nilai ROE naik sebesar satu satuan, maka nilai PER akan turun sebesar 0.252265 satuan.

d) Koefisien regresi PBV sebesar 0.861360 menunjukkan besarnya pengaruh PBV terhadap PER positif. Artinya, jika nilai PBV naik sebesar satu satuan, maka nilai PER akan naik sebesar 0.861360 satuan.

e) Koefisien regresi EPS_G sebesar -0.179422 menunjukkan besarnya pengaruh EPS_G terhadap PER negatif. Artinya, jika nilai EPS_G naik sebesar satu satuan, maka nilai PER akan turun sebesar 0.179422 satuan.

f) Koefisien regresi FLEV sebesar -4.590725 menunjukkan besarnya pengaruh FLEV terhadap PER negatif. Artinya, jika nilai FLEV naik sebesar satu satuan, maka nilai PER akan turun sebesar 4.590725 satuan.

\section{Uji t}

g)

a) Pengaruh DPR terhadap PER negatif dan signifikan yang ditunjukkan oleh nilai koefisien regresi sebesar -0.099816 dengan nilai t-hitung sebesar $|-2.108157|>t$-tabel $=\mathrm{t}_{0.025 ;(51-5-1)}=\mathrm{t}_{0.025 ; 45}=2.014$ dan probabilitas signifikansi sebesar $0.0406<0.05$. Dengan demikian hipotesis H1 terbukti.

b) Pengaruh ROE terhadap PER negatif dan tidak signifikan yang ditunjukkan oleh nilai koefisien regresi sebesar -0.252265 dengan nilai t-hitung sebesar $|-0.746092|<$ $\mathrm{t}_{\text {-tabel }}=\mathrm{t}_{0.025 ;(51-5-1)}=\mathrm{t}_{0.025 ; 45}=2.014$ dan probabilitas signifikansi sebesar 0.4595> 0.05 . Dengan demikian hipotesis $\mathrm{H} 2$ tidak terbukti.

c) Pengaruh PBV terhadap PER positif dan signifikan yang ditunjukkan oleh nilai koefisien regresi sebesar 0.861360 dengan nilai $\mathrm{t}$-hitung sebesar $2.250737>\mathrm{t}$-tabel $=\mathrm{t}$ $0.025 ;(51-5-1)=\mathrm{t} 0.025 ; 45=2.014$ dan probabilitas signifikansi sebesar $0.0293<0.05$. Dengan demikian hipotesis H3 terbukti.

d) Pengaruh EPS_G terhadap PER negatif dan tidak signifikan yang ditunjukkan oleh nilai koefisien regresi sebesar -0.179422 dengan nilai t-hitung sebesar $|-0.056535|<$ $\mathrm{t}_{- \text {tabel }}=\mathrm{t}_{0.025 ;(51-5-1)}=\mathrm{t}_{0.025 ; 45}=2.014$ dan probabilitas signifikansi sebesar $0.9552>$ 0.05. Dengan demikian hipotesis H4 tidak terbukti.

e) Pengaruh FLEV terhadap PER negatif dan tidak signifikan yang ditunjukkan oleh nilai koefisien regresi sebesar -4.590725 dengan nilai t-hitung sebesar $|-0.422352|<$ $\mathrm{t}_{\text {-tabel }}=\mathrm{t}_{0.025 ;(51-5-1)}=\mathrm{t}_{0.025 ; 45}=2.014$ dan probabilitas signifikansi sebesar $0.6748>$ 0.05. Dengan demikian hipotesis H5 tidak terbukti.

Uji signifikansi parameter simultan untuk menguji pengaruh variabel independen Dividend Payout Ratio, Return On Equity, Price Book Value, Earning Growth dan Financial Leverage secara bersama-sama terhadap variabel dependen Price Earning Ratio.Tabel VIII menunjukkan nilai statistik $\mathrm{F}$ sebesar 2.546283> $\mathrm{F}_{\text {-tabel }}=\mathrm{F}_{0.025 ; 5 ; 45}=2.42$ dan probabilitas signifikansi sebesar $0.041139<0.05$ dengan demikian pengaruh Dividend Payout Ratio, Return On Equity, Price Book Value, Earning Growth dan Financial Leverage secara bersama-sama terhadap variabel dependen Price Earning Ratio signifikan. Hal ini memberi arti hipotesis H6 terbukti. 
Uji Koefisien Determinasi. Koefisien determinasi untuk mengukur besarnya kontribusi variabel-variabel independen dalam menjelaskan variabilitas variabel dependen. Tabel VIII menunjukkan besarnya $R$-Squared sebesar 0.220528 dan Adjusted $R$-squared sebesar 0.133920. Artinya, besarnya kontribusi Dividend Payout Ratio, Return On Equity, Price Book Value, Earning Growth dan Financial Leverage secara bersama-sama dalam menjelaskan variabel Price Earning Ratiosebesar 13,39\% sedangkan sisanya sebesar 86,61\% dijelaskan oleh variabel lain yang dimasukkan dalam model atau tidak diteliti.

\section{PENUTUP}

Berdasarkan pengujian hipotesis yang sudah dilakukan sebelumnya menunjukkan Pengaruh DPR terhadap PER negatif dan signifikan.Saham dengan dividen yang tinggi merupakan salah satu faktor yang menarik bagi investor sehingga dapat menaikkan harga saham. Pengaruh ROE terhadap PER negatif tetapi tidak signifikan. Bila ROE meningkat, manajemen cenerung dipandang lebih efisien dari sudut pandang pemegang saham. Semakin besar tingkat pengembalian atas modal sendiri maka akan mendorong peningkatan harga saham.Pengaruh PBV terhadap PER positif dan signifikan. Untuk perusahaan-perusahaan yang berjalan dengan baik, umumnya rasio ini mencapai diatas satu, yang menunjukkan bahwa nilai pasar saham lebih besar dari nilai bukunya. Apabila PBV meningkat selanjutnya nilai PER akan meningkat.Pengaruh Earning Per Share Growthterhadap PER negatif dan tidak signifikan. investor dan calon investor tidak akan melakukan investasi pada saham perusahaan yang memiliki Earning Per Share Growth cenderung turun apalagi yang bernilai negatif. Pengaruh FLEV terhadap PER negatif dan tidak signifikan. Financial leveragecenderung tinggi hal ini tentunya akan menurunkan harga saham dan menurunkan minat investor dan calon investoruntuk melakukan investasi pada saham perusahaan yang memiliki Financial leverage yang tinggi.

Penelitian tentang PER ini hanya terbatas pada karakteristik saham-saham LQ 45 dan menggunakan lima variabel fundamental perusahaan (DPR, ROE,PBV,EG, dan FLEV). Untuk penelitian berikutnya, disarankan untuk meneliti lebih lanjut dan mempertimbangkan karakteristik lain seperti penilaian pada perusahaan selain saham LQ 45. Peneliti lain dapat menggunakan PER dengan menambahkan variabel yang berbeda, yang belum tercakup dalam penelitian ini dan juga memperbesar jumlah sampel.

\section{DAFTAR PUSTAKA}

Agnes Sawir. (2005).Analisis Kinerja Keuangan dan Perencanaan KeuanganPerusahaan.PT Gramedia Pustaka, Jakarta.

Agus Harjito, Martono. 2008. Manajemen Keuangan,edisi1.Yogyakarta: EKONISIA.

Brigham, Eugene F. And Ehrhardt, Michael C. (2011). Corporate Finance". $4{ }^{\text {th }}$ Edition. USA. South Western Cengage Learning. Ohio.

Darmadji, Tjiptono, dan Fakhrudin. (2012), Pasar Modal di Indonesia. Edisi Ketiga. Jakarta. Salemba Empat.

Fahmi, Irham. 2012. "Analisis Kinerja Keuangan", Bandung: Alfabeta

Halim, Abdul dan Mamduh M. Hanafi. 2009. Analisis Laporan Keuangan. Edisi 4. UPP STIM YKPN. Yogyakarta.

Husnan, Suad dan Enny Pudjiastuti. 2006. Dasar-Dasar Manajemen Keuangan. Edisi Kelima. UPP STIM YKPN : Yogyakarta.

Murhadi, Werner R. 2013. Analisis Laporan Keuangan, Proyeksi dan Valuasi Saham. Jakarta: Salemba Empat. 
Sudana, I. 2011. Manajemen Keuangan Perusahaan Teori dan Praktek. Jakarta : Erlangga. http://www.idx.co.id/

http://www.sahamok.com / 


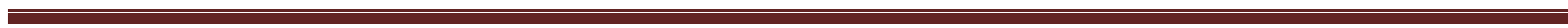
$\cdot$ 